\title{
Hemşirelik Bölümündeki Öğrencilerin Aldıkları Beslenme Eğitiminin Sağlık Davranışları, Antropometrik Ölçümler ve Beslenme Alışkanlıkları Üzerine Etkisinin Değerlendirilmesi
}

\author{
Sabiha Zeynep Aydenk Köseoğlu ${ }^{1 *}$, Berrak Baştürk ${ }^{2}$, Hatice Kübra Y1lmaz ${ }^{3}$ \\ ${ }^{1 *}$ Sabahattin Zaim Üniversitesi, Sağlık Bilimleri Fakültesi, Beslenme ve Diyetetik Bölümü, İstanbul, Türkiye, \\ (ORCID: https://orcid.org/0000-0001-7936-8642), sabiha.koseoglu@izu.edu.tr \\ ${ }^{2}$ Haliç Üniversitesi, Sağlı Bilimleri Fakültesi Beslenme ve Diyetetik Bölümü, İstanbul, Türkiye, \\ (ORCID: https://orcid.org/0000-0001-6817-3141), berrakerguden@ @alic.edu.tr \\ ${ }^{3}$ Haliç Üniversitesi, Sağlık Bilimleri Fakültesi Beslenme ve Diyetetik Bölümü, İstanbul, Türkiye, \\ (ORCID: https://orcid.org/0000-0001-7750-6024), kubrayilmaz@haliç.edu.tr
}

(İlk Geliş Tarihi 7 Eylül 2020 ve Kabul Tarihi 12 Ocak 2021)

(DOI: $10.31590 /$ ejosat.791686)

\begin{abstract}
ATIF/REFERENCE: Köseoğlu, S. Z. A., Baştürk, B. \& Yılmaz, H. K. (2021). Hemşirelik Bölümündeki Öğrencilerin Aldıkları Beslenme Eğitiminin Sağlık Davranışları, Antropometrik Ölçümler ve Beslenme Alışkanlıkları Üzerine Etkisinin Değerlendirilmesi. Avrupa Bilim ve Teknoloji Dergisi, (21), 216-222.
\end{abstract}

$\ddot{\mathbf{O z}}$

Bu çalışma, hemşirelik öğrencilerinin aldıkları beslenme eğitiminin, beslenme alışkanlıkları ve antropometrik ölçümlerine etkilerini değerlendirmek amacıyla yapıldı. 2017 Eylül - 2019 Eylül yılları arasında Haliç Üniversitesi Hemşirelik Bölümü öğrencilerinden gönüllü olanlardan, basit rastgele örnekleme yöntemiyle belirlenen, birinci sınıf öğrencisi 59 ve 56 üçüncü sınıf öğrencisi olmak üzere toplam 115 öğrenci çalışmaya dahil edildi. Öğrencilerin demografik özellikleri, sağlık durumları, beslenme alı̧̧kanlıkları, fiziksel aktivite düzeylerini sorgulayan bir anket yüz yüze uygulandı. Antropometrik ölçümlerinden boy stadiometre ile bel çevresi, kalça çevresi esnek şerit metre ile ağırlık, yağ ve kas yüzdesi ise bu konuda yetkin kişiler tarafindan BİA yöntemi ile ölçüldü. Çalışmaya katılan öğrenciler ortalama $21.2 \pm 2.38$ yaşlarında, çoğunun $(\% 73.9 ; n=85)$ kı olduğu belirlendi. BKİ'sinin \%71,3 çoğunlukla 18.524.9 arasında değiştiği ve normal sınırlar arasında olduğu, \%2.6'sının ise BKİ'sinin $30 \mathrm{~kg} / \mathrm{m}^{2}$ 'den büyük ve obez sınıfında olduğu saptandı. BKI'si $30 \mathrm{~kg} / \mathrm{m}^{2}$ 'den büyük olanların oranının üçüncü sınıf öğrencilerinde daha düşük (\%1.8) olduğu belirlendi. Bel çevresi $75 \mathrm{~cm}$ üzerinde olan öğrencilerin çoğunun birinci sınıf öğrencileri olduğu (\%35.5) üçüncü sınıf öğrencilerinde ise daha düşük olduğu (\%18.5) ve aralarında da istatistiksel olarak anlamlı farklılık olduğu belirlendi ( $\mathrm{p}=0,02)$. Çalışmaya katılan üçüncü sınıf öğrencilerinin \%40.3'ünün okulda aldığı beslenme dersinin beslenme alışkanlıkları üzerine etkili olduğunu ifade ettiği saptandı. Alınan beslenme dersinin öğrencilerin en çok kahvaltı öğününe (\%10.4) etkisi olduğu belirlendi. Çalışmanın sonucuna göre hemşirelik birinci sınıf ve üçüncü sınıf öğrencileri arasında aldıkları eğitim yönünden farklılık olmasına bağlı olarak bazı beslenme alışkanlıkları, antropometrik ölçümler ve sağlık davranışları arasında-farklılıklar görülmüştür.

Anahtar Kelimeler: Antropometrik Ölçümler, Beslenme Alışkanlıkları, Hemşirelik, Beslenme Eğitimi, Sağlık Davranışları.

\section{Assessment of the Effect of Nutrition Education Received by Students in Nursing Department on Health Behaviors, Anthropometric Measurements and Nutritional Habits}

\begin{abstract}
This study was carried out to evaluate the effects of the nutritional education received by nursing students on nutritional habits and anthropometric measurements. Between September 2017 and September 2019, among the volunteers of Haliç University Nursing Department, a total of 115 students, 59 first-year students and 56 third-year students, determined by simple random sampling method,
\end{abstract}

\footnotetext{
*Sorumlu Yazar: szaydenk@gmail.com
} 
were included in the study. A questionnaire questioning the demographic characteristics, health status, nutritional habits, and physical activity levels of the students was applied face-to-face. Among the anthropometric measurements, height was measured with a stadiometer, waist circumference, hip circumference were measured with a flexible tape measure, and weight, fat and muscle percentage were measured with the BIA method by competent persons. The students participating in the study were determined to be $21.2 \pm 2.38$ years old, most of them $(73.9 \% ; n=85)$ girls. It was determined that the BMI was between the normal limits $71.3 \%$, mostly between $18.5-24.9$, and the BMI of $2.6 \%$ was above $30 \mathrm{~kg} / \mathrm{m}^{2}$ and in the obese class. It was determined that the ratio of those with a BMI greater than $30 \mathrm{~kg} / \mathrm{m}^{2}$ was lower $(1.8 \%)$ in third-year students. It was determined that most of the students with waist circumference above $75 \mathrm{~cm}$ were first-year students (35.5\%) and lower than third-year students (18.5\%) and there was a statistically significant difference between them $(\mathrm{p}=0.02) .40 .3 \%$ of the third-year students who participated in the study stated that they were effective on the habits of the nutrition lesson they took at school. It was determined that the nutrition lesson learned had the most effect on students' breakfast meals (10.4\%). According to the results of the study, some changes in terms of nutritional habits, anthropometric measurements and health behaviors were observed due to the differences between the first, and third-years of Nursing students in terms of education they received.

Keywords: Anthropometric Measurements, Nutritional Habits, Nursing, Nutrition Education, Health Behaviors.

\section{Giriş}

Sağlıklı ve dengeli beslenme; büyüme, gelişme, sağlı̆̆ korumak ve yaşam kalitesinin ve yükseltilmesinde gereksinimimiz ölçüsünde enerji ve besin öğelerinin yeterli ve zamanında alınması yönünden büyük öneme sahiptir (Baysal, 2012).

Çocukluk ve gençlik dönemleri, sağlıklı yaşam şeklinin edinilmesi, sürdürülmesi, uygun beslenme davranışlarının kazanılması ve yaşamın ileri dönemlerine taşınmasında önemlidir. Son yıllardaki araştırmaların sonuçları, bu dönemlerdeki sağlıksız beslenme alışkanlıklarının yetişkinlik döneminde görülen kronik hastalıkların nedeni olduğunu göstermektedir (C. Baric, Šatalić \& Lukešić, 2003; Benjelloun, 2002). Kalp damar hastalıkları, diyabet, obezite, osteoporoz ve kanserlerin oluşumunda o zamana değin alınan kalori miktarı ve bunun bileşimi önemli rol oynamaktadır (Mazıcıoğlu, \& Öztürk, 2003).

Beslenme, bugünlerde bütün ülkeler tarafindan önem verilen bir konu olup, kişilerin temel ihtiyaçlarından birisidir. Anne karnından başlayarak, yaşamın tüm evrelerinde doğru beslenme alışkanlıklarının edinilmesi ve düzenlenmesi, özellikle beden ve akıl sağlığının korunması ve gelişimi yönünden önem taşımaktadır (Benjelloun, 2002).

Beslenmenin izlenmesinde, günlük öğün miktarı, gün içinde tüm öğünlerde tüketilen gıdaların cins, içerik ve miktarları, besin tercihleri, besinlerin satın alınması, saklanması, hijyenik ve sağlıklı olarak pişirilmesine yönelik alışkanlıklarıyla, birlikte yemekleri yerken çiğneme durumları, beslenme hızları, psikolojik durumlara göre beslenme davranış ve tutumları gibi konuları içermektedir (Kaleli, 2017).

Günlük beslenmede gereksinimlerin hesaplanmasında yaş, cinsiyet, sağlık durumu, yapılan fiziksel aktivite ve kalıtsal etmenler değerlendirilmektedir. Adölesan dönemindeki tüm gereksinimler yetişkinlerden daha fazladır. Yetersiz ve dengesiz beslenmenin yol açtığ sorunların en çok rastlandığ 1 yaş gruplarından birisidir. Üniversite, gençlerin hayatında pek çok konuda olduğu gibi beslenme konusunda da yeni bir dönem olarak kabul edilmektedir. $\mathrm{Bu}$ süreçte gençler yeni oluşturacakları düzene uyum sağlamakla birlikte, farklı pek çok insanla iletişime geçmeleri sebebiyle de diş etkilere daha fazla açık hale gelirler ve bu dönemde normalde gösterdiklerinden farklı davranışlar sergileyebilirler. Hayatlarının daha aktif hale gelmesi ile birlikte sağlıksı ve düzensiz beslenme davranışlarının artmasına neden olmaktadır (Mazıcığlu \& Öztürk, 2003).

Üniversite gençliği, adölesan sonrası yetişkinliğe adım atma aşamasındaki önemli bir grubu teşkil etmektedir. Bu dönemdeki öğrenciler, alışmış oldukları aile ortamından ayrılmakta, sosyalleşmeleri ve kendi tercihlerini yapmalarından dolayı da beslenme planlarında değişik formasyonları seçebilmekte ve bu yaklaşımlar onların sağlık sorunlarına neden olabilmektedir (Korkmaz, 2010). Üniversitede öğrenim gören öğrencilerin beslenme alışkanlıklarının, gereksinimlerinin saptanması ve planlanması, bu dönemde görülebilecek beslenme sorunlarının önlenmesi yönünden önem taşımaktadır (Ermiş, 2015).

Beslenme, beslenme alışkanlıklarındaki değişiklik daha sağlıklı bir yaşam ve uzun ömürle sonuçlanabileceği için akademik ve kamusal öneme sahip bir konudur. Sağlıkla ilgili eğitim veren birçok üniversite, beslenme eğitimine yönelik müfredatlar geliştirmeye çalışmaktadır. Ancak, sağlık profesyonellerinin halen beslenme bilgilerinde ciddi eksiklikleri olduğuna dair kanıtlar vardır. Dahası, sağlık bilimi öğrencileri sağlıklı beslenmeyi kabul etmiyor gibi görünmekte ve beslenme bilgisi ve beslenme müfredatlarının etkinliği ile ilgili sorular ortaya atılmaktadır (Yfanti, Tsiriga, Yfantis \& Tiniakou, 2011).

Sağlık hizmeti sağlayıcıları, optimal olmayan beslenme ve yaşam tarzı modellerine katkıda bulunan tüm yaşam tarzı ve çevresel faktörleri göz önünde bulundurmalıdır. Ayrıca, toplum sağlık hizmetlerinde çalışan hemşireler her yaş grubunun sağlık taranmasında ve tedavisine katılarak önemli bir rol oynayabilir. $\mathrm{Bu}$ nedenle ve çoğu beslenme tedavisi diyetisyenler tarafından uygulanmakla birlikte, hemşirelerin beslenme riski faktörlerini tanımlamak için yeterli bilgiye sahip olmaları gerekmektedir (Endevelt, 2009).

\section{Materyal ve Metot 2.1. Araştırmanın Amacı}

Çalışmada sağlık profesyonellerinden biri olan hemşirelerin beslenme ve sağlık dersini henüz almamış olan hemşirelik 1.Sınıf öğrencileri ile beslenme ve sağlık konusunda eğitim almış olan 3.Sınıf öğrencileri arasındaki beslenme, sağlık davranışları ve bu parametrelerden etkilenen antropometrik ölçümler yönünden değerlendirilmesi amaçlandı.

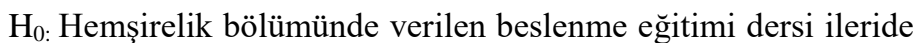
edinilen beslenme alışkanlıkları üzerine etkili değildir. 
$\mathrm{H}_{1:}$ Hemşirelik bölümünde verilen beslenme eğitimi dersi ileride edinilen beslenme alışkanlıkları üzerine etkilidir.

$\mathrm{Bu}$ araştırmada aşağıdaki sorulara yanıt arandı: Beslenme eğitimi alan öğrencilerle beslenme eğitimi almayan öğrenciler arasında;

1. Antropometrik ölçümler arasında anlamlı farklılık var mıdır?

2. Beslenme alışkanlıkları arasında anlamlı farklılık var mıdır?

3. Sağlık davranışları arasında anlamlı farklılık var mıdır?

\subsection{Araștırmanın Evren ve Örneklemi}

Araştırma, Eylül 2017-Ocak 2019 döneminde gerçekleştirilip, çalışmaya Haliç Üniversitesi Hemşirelik Yüksekokulu 1. ve 3.Sınıf öğrencilerden oluşan 115 öğrenci dahil edildi. Çalışmada birinci ve üçüncü sınıfların seçilme nedeni; 1.Sınıfta beslenme eğitiminin olmaması, 3.Sınıfta beslenme eğitiminin bulunmasına bağlı olarak beslenme eğitimlerinin sağlık davranışları ve beslenme alışkanlıkları, ilaveten de antropometrik ölçümler üzerine etkisini değerlendirmek amacının güdülmesiydi. Araştırmanın evrenini 2017-2019 Öğretim Yılı'nda öğrenim gören 250 öğrenci oluşturdu. Örneklem sayısını belirlemede evreni belli olan örneklem formülü kullanıldı. Buna göre araştırmaya dahil etmemiz gereken en az sayı 151.68 iken ancak örneklem sayısı araştırmaya katılmayı kabul eden gönüllü öğrencilerden oluşturulabildi. Araştırma 1.Sınıf'lardan 59 öğrenci ve 3.Sınıf'lardan 56 olmak üzere 115 öğrenci ile tamamlanabildi.

\subsection{Veri Toplama Araçları}

Çalışmada veri toplama aracı olarak öğrencilerin sosyodemografik özellikleri, sağlık durumları, beslenme alışkanlıkları ve eğitim sürecinin bu alışkanlıkları üzerine etkilerini içeren anket formu, BİA yöntemiyle çalışan Yağ-Kas Ölçüm Cihazı (Tanita BC418 MA), boy ölçümü için stadiometre ve bel çevresi, kalça çevresi ölçümü için ise esnek şerit metre kullanıld1.

\subsection{Veri Toplama Araçlarının Uygulanması}

Yüz yüze görüşülerek uygulanan anket formuyla öğrencilerin bazı tanımlayıcı özellikleri (yaş, cins, bulundukları sınıf, etnik köken, aile gelir düzeyi), sağlık durumları (alkol, sigara kullanımları, sistemsel hastalıkları, kullandıkları ilaç ve vitamin, mineral takviyeleri), beslenme alışkanlıkları ve eğitim sürecinin bu alışkanlıkları üzerine etkileri ile ilgili bilgi toplandı. Öğrencilerin Beden Kütle İndeksleri, ağırlık (Tanita BC418 MA ile ölçülen) ve boy ölçümleri (Stadiometre ile alınan) formülasyonda $(\mathrm{kg} / \mathrm{m} 2)$ yerine konarak hesapland1. Dünya Sağlık Örgütü (DSÖ)'nün sınıflandırması referans olarak alındı. $\mathrm{Bu}$ sinıflandirmaya göre; BKİ $<18.5 \mathrm{~kg} / \mathrm{m} 2$ olanlar "Zayıf", 18.5-24.9 kg/m2 arasinda olanlar "Normal", 25.0-29.9 kg/m2 arasında olan bireyler "Hafif Şişman", 30.0-34.9 kg/m2 arasında olanlar "2.Derece Obez" ve $>40 \mathrm{~kg} / \mathrm{m} 2$ olanlar "3.Derece Obez" olarak değerlendirildi (DSÖ 2004).

Beslenme durumunun değerlendirilmesinde diğer önemli bir ölçüt olan; Bel ve Kalça Ölçümü (BKÖ) esnek bir şerit metre ile araştırmacılar tarafından alındı. Bel ve kalça ölçümlerinin oranına bakılarak, standartlarla karşılaştırıldı. DSÖ sınıflamasına göre; Bel Kalça Oranı (BKO) kadın ve erkekte değişkenlik gösterdiğinden; kadınlarda $\mathrm{BKO}$ değeri 0.80 veya altında ise sağlık riskinin düşük, 0.81-0.85 ise orta derecede sağlık riskleri bulunduğu ve 0.86 veya üzerinde ise yüksek risk grubunda olunduğu; erkeklerde ise 0.95 veya altında ise düşük riske sahip olunduğu, 0.96-1.0 ise orta derecede risk bulunduğu ve 1.0 veya daha üzerinde ise yüksek risk taşıdıkları şeklindeki standartlarla (DSÖ, 2008) karşılaştırılarak sağlık bakımından risk grubunda olup olmadıkları belirlendi.

\subsection{Araştırmanın Etik Boyutu}

Çalışmaya başlamadan önce, Haliç Üniversitesi Girişimsel Olmayan Klinik Araştırmalar Etik Kurulu'ndan etik izin (112016/1116), Hemşirelik Yüksekokulu Müdürlügü̈nden kurum izni ve araştırmaya katılan gönüllü öğrencilerden de yazılı onam formu alındi.

\subsection{Verilerin Analizi}

Tüm verilerin istatistiksel olarak değerlendirilmesinde SPSS 16.0 istatistiksel programı kullanmıştır. Sürekli ve kesikli sayısal değişkenlerin dağılımının normallik analizi Kolmogorov Smirnov Testi, Skewnes ve Kurtosis $(-1,5$ ve $+1,5)$ ve $n \geq 30$ ile varyansların homojenliği ise Levene Testi ile araştırılmış olup, tanımlayıcı istatistikler sürekli ve kesikli sayısal değişkenler için ortalama, standart sapma, medyan, en düşük ve en yüksek şeklinde, kategorik değişkenler ise olgu sayısı ve (\%) biçiminde gösterilmiştir. İki veya daha fazla değişken arasında anlamlılığın saptanması için Student's T Testi ve Tek Yönlü Varyans Analizi kullanılmıştır.

\section{Araştırma Sonuçları ve Tartışma 3.1. Araştırma Sonuçları}

Çalışmaya katılan 115 öğrencinin yaş ortalaması $21.2 \pm 2.38$ yıl olup çalışmada 18-33 yaş aralığında katılımcıların \%73.9 'u $(n=85)$ k1z olup \%26.1'i $(n=30)$ erkektir. Öğrencilerin sinıf dağılım durumları incelendiğinde \%50.4 'ünün 1.Sınıf, \%47.8 'inin 3.Sınıf olduğu saptanmıştır. Ayrıca, katılımcı öğrencilerin $\% 67.5$ 'i orta gelir düzeyine sahiptir.

DSÖ’ye göre incelendiğinde; çalışmadaki tüm öğrencilerin (1.Sınıf ve 3.Sınıf öğrencileri) \%8.7'sinin “Zayıf” $(<18.5$ $\left.\mathrm{kg} / \mathrm{m}^{2}\right), \% 71.3$ 'ünün "Normal” beden kütle indeksinde (18.5$\left.24.9 \mathrm{~kg} / \mathrm{m}^{2}\right), \% 17.4$ 'ünün "Hafif Şişman” aralığında (25-29.9 $\mathrm{kg} / \mathrm{m} 2)$ ve \%2.6'sının “Şişman” (>30 kg/m2) olduğu saptandı. Tablo 1'de katılımcıların sinıflara göre BKI 'leri ele alındığında ise; 1. ve 3.Sınıf öğrencilerinin BKIdeğerleri arasında anlamlı fark saptanmamış olup ( $\mathrm{p}=0.19)$, 1.Sınıfların \%77.9'unun; 3.Sinıfların \%64,3'ünün "Normal” BKI (18.5-24.9 kg/m²) aralığında olduğu belirlendi. Anlamlı farklılık 1. ve 3. Sınıfların bel çevresi değerleri arasında bulunmuş olup $(p=0.04)$ bel çevresi $75 \mathrm{~cm}$ den büyük olanların oranı 1.Sınıflarda \%67.8 iken 3.Sinıflarda \%39.3 olarak saptandı (Tablo 1). 
Tablo 1. Öğrencilerin Antropometrik Ölçümleri (n=115)

\begin{tabular}{|c|c|c|c|c|c|}
\hline \multirow[t]{2}{*}{$\begin{array}{l}\text { BKI }\left(\mathrm{kg} / \mathrm{m}^{2}\right) \\
(\mathrm{n}=115)\end{array}$} & \multicolumn{2}{|c|}{$\begin{array}{l}\text { l.Sinif } \\
(n=59)\end{array}$} & \multicolumn{2}{|c|}{$\begin{array}{l}\text { 3.Smif } \\
(\mathrm{n}=56)\end{array}$} & \multirow[t]{2}{*}{$\mathrm{p}, \mathrm{x}^{2}$} \\
\hline & $\mathbf{n}$ & $\%$ & $\mathbf{n}$ & $\%$ & \\
\hline$<18.5$ & 5 & 8.5 & 5 & 8.9 & \multirow{3}{*}{$\begin{array}{l}\mathrm{p}=0.19 \\
\mathrm{x} 2=3.27\end{array}$} \\
\hline $18.5-24.9$ & 46 & 77.9 & 36 & 64.3 & \\
\hline$>25$ & 8 & 13.6 & 15 & 26.8 & \\
\hline \multicolumn{6}{|c|}{ Bel Çevresi (cm) } \\
\hline $56-65$ & 6 & 10.2 & 11 & 19.6 & \multirow{3}{*}{$\begin{array}{l}\mathrm{p}=0.04^{*} \\
\mathrm{x}^{2}=9.40\end{array}$} \\
\hline $66-74.9$ & 13 & 22.0 & 23 & 41.1 & \\
\hline$>75$ & 40 & 67.8 & 22 & 39.3 & \\
\hline \multicolumn{6}{|c|}{ Kalça Çevresi (cm) } \\
\hline $80-91.9$ & 17 & 28.8 & 13 & 23.2 & \multirow{3}{*}{$\begin{array}{l}p=0.26 \\
x 2=2.64\end{array}$} \\
\hline $92-103.9$ & 35 & 59.3 & 30 & 53.6 & \\
\hline$>104$ & 7 & 11.9 & 13 & 23.2 & \\
\hline \multicolumn{6}{|c|}{ Yağ Yüzdesi (\%) } \\
\hline $0-10.9$ & 6 & 10.2 & 6 & 10.7 & \multirow{5}{*}{$\begin{array}{l}\mathrm{p}=0.78 \\
\mathrm{x}^{2}=2.44\end{array}$} \\
\hline $11-16.9$ & 13 & 22.0 & 8 & 14.3 & \\
\hline $17-22.9$ & 15 & 25.4 & 15 & 26.8 & \\
\hline $23-28.9$ & 12 & 20.4 & 15 & 26.8 & \\
\hline$>29$ & 13 & 22.0 & 12 & 21.4 & \\
\hline
\end{tabular}

${ }^{*} \mathrm{p}<0,05$

Öğrencilerin BKO düzeylerinin sınıf ve cinsiyete göre dağılımı Tablo 2'de verilmiştir. BKO'su 0.8'in altında ve üzerinde olan kadınların sayısı sınıflara dair incelemelerinde, aralarında istatiksel olarak anlamlı bir ilişki saptandı $(p=0.03)$. Erkek ögrencilerin katılımcı olarak az sayıda olmaları nedeniyle p değerleri hesaplanamadi.

Çalışmaya katılan bütün öğrencilerin (1.Sınıf ve 3.Sınıf) beslenme alışkanlıkları incelendiğinde; katılımcılarda \%69.6' sının kahvaltı alışkanlığı olduğu ve sınflarının dağılımına göre ise 1.Sınıfların \%67.8'inin ve 3.Sınıfların \%71.4'ünün sabahları kahvaltı yaptığı saptanmış olup,1.Sınıflar ile 3.Sınıflar arasında kahvaltı alışkanlığı bakımından anlamlı fark bulunmadı $(\mathrm{p}=0.79)$. Katılımcıların \%50.4'ünün kahvaltısını evde yaptığı belirlendi.

Tablo 2. Öğrencilerin BKO Değerlerinin Smıf ve Cinsiyete Göre Dağılımı (n=115)

\begin{tabular}{|c|c|c|c|c|}
\hline \multicolumn{2}{|c|}{ Bel / Kalça Oranı } & \multirow{2}{*}{$\begin{array}{l}\text { l.Smnf } \\
(n=45)\end{array}$} & \multirow{2}{*}{$\begin{array}{l}\text { 3.Smif } \\
(\mathrm{n}=40)\end{array}$} & \multirow{3}{*}{$\begin{array}{l}\mathbf{p}, \mathbf{x}^{2} \\
\mathrm{p}=0.03^{*} \\
\mathrm{x}^{2}=0.04\end{array}$} \\
\hline \multirow[t]{2}{*}{ Kadin } & $<0,8$ & & & \\
\hline & 0,8 ve üzeri & 16 & 6 & \\
\hline & & $\begin{array}{l}\text { l.Smif } \\
(n=14)\end{array}$ & $\begin{array}{l}\text { 3.Sinif } \\
(\mathrm{n}=16)\end{array}$ & \\
\hline \multirow[t]{2}{*}{ Erkek } & $<0,9$ & 11 & 14 & \\
\hline & 0,9 ve üzeri & 3 & 2 & \\
\hline
\end{tabular}

Bütün öğrencilerin (1.Sınıf ve 3.Sınıflar) \%40.9'unun öğle yemeği yediği \%52.2'sinin öğle yemeği yemediği tespit edildi. 1.Sınıfların beslenme eğitimi almadan \%33.9 olan öğle yemeği tüketimi, eğitim sonrası (3.Sınıflar) \%48.2'ye yükseldi $(\mathrm{p}=0.16)$. Çalışmaya alınan bütün katılımcılar arasında öğle yemeğinde en fazla et-balık-tavuk tüketildiği (\%40.9) saptandı.

Çalışmadaki tüm öğrencilerin (1.Sınıf ve 3.Sınıflar) \%76.5'inin akşam yemeğini atlamadığı ve \%66.1'inin evinde akşam yemeğini yediği, dışarda akşam yemeği yiyenlerin oranının \%7 olduğu tespit edildi. Akşam yemeğinde de öğle yemeği ile benzer olarak en fazla et-balık-tavuk tüketildiğ (\%33), meyve yiyenlerinin oranının \%0.9 olduğu bulundu. 1 . ve 3.Sınıfların akşam yemeğini tüketip tüketmeme durumları arasında anlamlı bir farklılık saptanmadı (Tablo 3).

Tablo 3. Katılımcıların Sinıflarına Göre Ana Oğün Yapma Durumlarn (n=115)

\begin{tabular}{|c|c|c|c|c|c|}
\hline & \multicolumn{2}{|c|}{$\begin{array}{l}\text { l.Smif } \\
(n=59)\end{array}$} & \multicolumn{2}{|c|}{$\begin{array}{l}\text { 3.Sinif } \\
(n=56)\end{array}$} & \\
\hline $\begin{array}{l}\text { Kahvaltı etme } \\
\text { durumu }\end{array}$ & $\mathbf{n}$ & $\%$ & $\mathbf{n}$ & $\%$ & $p, x^{2}$ \\
\hline Evet & 40 & 67.8 & 40 & 71.4 & \multirow{3}{*}{$\begin{array}{l}p=0.79 \\
x^{2}=4.07\end{array}$} \\
\hline Hayır & 5 & 8.5 & 3 & 5.4 & \\
\hline Bazen & 14 & 23.7 & 13 & 23.2 & \\
\hline $\begin{array}{l}{ }^{*} \text { Kahvaltıda } \\
\text { yenilen besinler }\end{array}$ & \multicolumn{2}{|c|}{$\begin{array}{l}\text { 1.Smif } \\
(n=10)\end{array}$} & \multicolumn{2}{|c|}{$\begin{array}{l}\text { 3.Sinif } \\
(\mathrm{n}=\mathbf{2 0})\end{array}$} & \\
\hline Simit & 1 & 10 & 1 & 5 & \\
\hline Poğaça & 1 & 10 & 2 & 10 & \\
\hline Tost & 0 & 0.0 & 2 & 10 & \\
\hline Kahvaltı menüsü & 4 & 40 & 10 & 50 & \\
\hline Karıșık & 4 & 40 & 5 & 25 & \\
\hline $\begin{array}{l}\text { Kahvaltı edilen } \\
\text { yer }\end{array}$ & \multicolumn{2}{|c|}{$\begin{array}{l}\text { l.Sinif } \\
(n=59)\end{array}$} & \multicolumn{2}{|c|}{$\begin{array}{l}\text { 3.Sinif } \\
(n=56)\end{array}$} & \\
\hline Evde & 29 & 49.2 & 29 & 51.8 & \\
\hline Yurtta & 15 & 25.4 & 7 & 12.5 & $p=0.39$ \\
\hline Okulda & 5 & 8.5 & 6 & 10.7 & $x^{2}=4.06$ \\
\hline Dişarda & 10 & 17.0 & 14 & 25 & \\
\hline $\begin{array}{l}\text { Öğle yemeği } \\
\text { yeme durumu }\end{array}$ & \multicolumn{2}{|c|}{$\begin{array}{l}\text { l.Sinif } \\
(n=59)\end{array}$} & \multicolumn{2}{|c|}{$\begin{array}{l}\text { 3.Sinif } \\
(n=56)\end{array}$} & \\
\hline Evet & 20 & 33.9 & 27 & 48.2 & $p=0.16$ \\
\hline Hayır & 33 & 55.9 & 27 & 48.2 & $x^{2}=3.56$ \\
\hline Bazen & 6 & 10.2 & 2 & 3.6 & \\
\hline $\begin{array}{l}* \text { Öğle yemeğinde } \\
\text { yenilen besinler }\end{array}$ & \multicolumn{2}{|c|}{$\begin{array}{l}\text { l.Sinif } \\
(\mathrm{n}=53)\end{array}$} & \multicolumn{2}{|c|}{$\begin{array}{l}\text { 3.Sinif } \\
(n=54)\end{array}$} & \\
\hline Süt - yoğurt & 1 & 1.9 & 1 & 1.8 & \\
\hline Et - balik-tavuk & 23 & 43.4 & 24 & 44.4 & \\
\hline Sebze & 3 & 5.7 & 7 & 13.0 & \\
\hline Tahıl & 4 & 7.5 & 1 & 1.8 & \\
\hline Meyve & 4 & 7.5 & 1 & 1.8 & \\
\hline Karıșık & 18 & 34.0 & 20 & 37.0 & \\
\hline $\begin{array}{l}\text { Akșam yemeği } \\
\text { yeme durumu }\end{array}$ & \multicolumn{2}{|c|}{$\begin{array}{l}\text { l.Smif } \\
(n=59)\end{array}$} & \multicolumn{2}{|c|}{$\begin{array}{l}\text { 3.Sinif } \\
(n=56)\end{array}$} & \\
\hline Evet & 45 & 76.3 & 43 & 76.8 & \\
\hline Hayır & 9 & 15.3 & 8 & 14.3 & $\mathrm{p}=0.98$ \\
\hline Bazen & 5 & 8.5 & 5 & 8.9 & \\
\hline $\begin{array}{l}\text { *Akșam } \\
\text { yemeğinde } \\
\text { yenilen besinler }\end{array}$ & \multicolumn{2}{|c|}{$\begin{array}{l}\text { l.Sinif } \\
(n=56)\end{array}$} & \multicolumn{2}{|c|}{$\begin{array}{l}\text { 3.Sinif } \\
(n=54)\end{array}$} & \\
\hline Süt - yoğurt & 1 & 1.78 & 0 & 0.0 & \\
\hline Et - balık -tavuk & 17 & 30.3 & 21 & 38.9 & \\
\hline Sebze & 4 & 7.1 & 7 & 13.0 & \\
\hline Tahil & 4 & 7.1 & 1 & 1.8 & \\
\hline Meyve & 0 & 0.0 & 1 & 1.8 & \\
\hline Karıșık & 30 & 53.6 & 24 & 44.4 & \\
\hline $\begin{array}{l}\text { *Akșam yemeği } \\
\text { yenilen yer }\end{array}$ & \multicolumn{2}{|c|}{$\begin{array}{l}\text { l.Sinif } \\
(n=56)\end{array}$} & \multicolumn{2}{|c|}{$\begin{array}{l}\text { 3.Sinif } \\
(n=54)\end{array}$} & \\
\hline Evde & 37 & 66.1 & 39 & 72.2 & \\
\hline Yurtta & 0 & 0.0 & 3 & 5.5 & \\
\hline Okulda & 15 & 26.8 & 7 & 12.9 & \\
\hline Dişarda & 4 & 7.2 & 5 & 9.2 & \\
\hline
\end{tabular}

* p ve ki-kare değerleri saptanmamıştır.

Bütün katılımcıların ara öğün tüketim düzeyleri sorgulandığında \%31.3'ünün ara öğün tükettiği, \%41.7'sinin bazen ara öğün tükettiği saptandı. 1.Sinıfların \%28.8'inin, 3.Sınıfların \%33.9'unun ara öğün tükettiği bulunmuş olup ara öğün tüketimleri arasında anlamlı fark bulunmadı $(\mathrm{p}=0.81)$. Ara 
öğünde 1.Sınıfların tükettiği besinler arasında süt-yoğurt yok iken 3.Sınıflardan ara öğün yapan katılımcıların \%9.7'sinin sütyoğurt tükettiği saptandı. Fakat öğrencilerin ara öğ̈̈n tüketimlerinde tercih ettiği besinler arasında anlamlı fark bulunmadı $(\mathrm{p}=0.36)$ (Tablo 4).

Tablo 4. Katılımcılarm Sinflarına Göre Ara Öğün Yapma Durumları

\begin{tabular}{|c|c|c|c|c|c|}
\hline \multirow[t]{2}{*}{$\begin{array}{l}\text { Ara Öğün Tüketim } \\
\text { Durumu }\end{array}$} & \multicolumn{2}{|c|}{$\begin{array}{l}\text { l.Sinif } \\
(n=59)\end{array}$} & \multicolumn{2}{|c|}{$\begin{array}{l}\text { 3.Sinif } \\
(\mathrm{n}=56)\end{array}$} & \multirow[t]{2}{*}{$\mathbf{p}, \mathbf{x}^{2}$} \\
\hline & $\mathbf{n}$ & $\%$ & $\mathbf{n}$ & $\%$ & \\
\hline Evet & 17 & 28.8 & 19 & 33.9 & $\mathrm{p}=0.81$ \\
\hline Hayir & 16 & 27.1 & 15 & 26.8 & $\mathrm{x}^{2}=0.39$ \\
\hline Bazen & 26 & 44.1 & 22 & 39.3 & \\
\hline $\begin{array}{l}\text { *Ara Öğ̈ülerde } \\
\text { Tüketilen Besinler }\end{array}$ & \multicolumn{2}{|c|}{$\begin{array}{l}\text { l.Sinıf } \\
(n=43)\end{array}$} & \multicolumn{2}{|c|}{$\begin{array}{l}\text { 3.Sinif } \\
(n=41)\end{array}$} & \\
\hline Süt - yoğurt & 0 & 0.0 & 4 & 9.7 & \\
\hline Meyve suyu & 0 & 0.0 & 1 & 2.4 & \\
\hline Hazır meșrubat & 1 & 2.3 & 2 & 4.8 & \\
\hline Çay - kahve & 1 & 2.3 & 3 & 7.2 & \\
\hline Kek-kurabiye & 2 & 4.6 & 1 & 2.4 & \\
\hline Tost & 1 & 2.3 & 1 & 2.4 & \\
\hline Bisküvi & 2 & 4.6 & 3 & 7.2 & \\
\hline Meyve & 0 & 0.0 & 1 & 2.4 & \\
\hline Çikolata & 1 & 2.3 & 0 & 0.0 & \\
\hline Kuruyemiş & 1 & 2.3 & 1 & 2.4 & \\
\hline Fast - food & 0 & 0.0 & 1 & 2.4 & \\
\hline Karıșık & 34 & 79.1 & 23 & 56.1 & \\
\hline
\end{tabular}

*p ve ki-kare değerleri saptanmamıştır.

Öğrencilerin hepsinin \%53.9'unun öğle ve akşam yemeklerinde bazen hazır yemek tercih ettiği saptandı. 1.Sinıfların \%27.2'sinin, 3.Sınıfların \%25'inin hazır besin tercih ettiği saptanmış olup, aralarında anlamlı bir fark bulunmadı (Tablo 5).

Tablo 5. Beslenme Alışkanlıkları ve Beslenme ile İlgili Değișkenlerin Değerlendirilmesi

\begin{tabular}{|c|c|c|c|c|c|}
\hline & \multicolumn{2}{|c|}{$\begin{array}{l}\text { 1.Sinif } \\
(\mathrm{n}=59)\end{array}$} & \multicolumn{2}{|c|}{$\begin{array}{l}\text { 3.Sinif } \\
(\mathrm{n}=56)\end{array}$} & \multirow[t]{2}{*}{$\mathrm{p}, \mathrm{x}^{2}$} \\
\hline $\begin{array}{l}\text { Hazir Besinleri Tercih } \\
\text { Etme Durumu }\end{array}$ & $\mathbf{n}$ & $\%$ & $\mathbf{n}$ & $\%$ & \\
\hline Evet & 16 & 27.2 & 14 & 25 & \multirow{3}{*}{$\begin{array}{l}\mathrm{p}=0.92 \\
\mathrm{x}^{2}=0.16\end{array}$} \\
\hline Hayır & 11 & 18.6 & 12 & 21.4 & \\
\hline Bazen & 32 & 54.3 & 30 & 53.6 & \\
\hline & \multicolumn{2}{|c|}{$\begin{array}{l}\text { l.Sinıf } \\
(n=59)\end{array}$} & \multicolumn{2}{|c|}{$\begin{array}{l}\text { 3.Sinif } \\
(n=56)\end{array}$} & \\
\hline $\begin{array}{l}\text { Beslenme Programı } \\
\text { Uygulama }\end{array}$ & $\mathbf{n}$ & $\%$ & $\mathbf{n}$ & $\%$ & \\
\hline Evet & 13 & 22.1 & 7 & 12.5 & $\mathrm{p}=0.17$ \\
\hline \multirow[t]{2}{*}{ Hayır } & 46 & 77.9 & 49 & 87.5 & $\mathrm{x}^{2}=0.22$ \\
\hline & \multicolumn{2}{|c|}{$\begin{array}{l}\text { l.Sinıf } \\
(\mathrm{n}=13)\end{array}$} & \multicolumn{2}{|c|}{$\begin{array}{c}\text { 3.Sinif } \\
(n=7)\end{array}$} & \\
\hline $\begin{array}{l}\text { Beslenme Programı } \\
\text { Edinilen Kişi }\end{array}$ & $\mathbf{n}$ & $\%$ & $\mathbf{n}$ & $\%$ & \\
\hline Kendisi & 7 & 53.8 & 5 & 71.4 & $\mathrm{p}=0.24$ \\
\hline \multirow[t]{2}{*}{ Diyetisyen } & 6 & 46.2 & 2 & 28.6 & $x^{2}=2.78$ \\
\hline & \multicolumn{2}{|c|}{$\begin{array}{l}\text { l.Sinif } \\
(n=59)\end{array}$} & \multicolumn{2}{|c|}{$\begin{array}{l}\text { 3.Sinif } \\
(n=56)\end{array}$} & \\
\hline $\begin{array}{l}\text { Beslenme Dersinin } \\
\text { Davranış Değişikliğine } \\
\text { Etkisi }\end{array}$ & $\mathbf{n}$ & $\%$ & $\mathbf{n}$ & $\%$ & \\
\hline Evet & 10 & 16.9 & 23 & 41.1 & \multirow{2}{*}{$\begin{array}{l}\mathrm{p}=0.04 \\
\mathrm{x}^{2}=8.17\end{array}$} \\
\hline Hayır & 49 & 83.1 & 33 & 58.9 & \\
\hline
\end{tabular}

Çalışmaya katılan tüm öğrencilerin \%28.7'si okulda aldıkları, beslenme dersinin sağlık alışkanlıkları üzerine etkili olduğunu belirtmişlerdir. Sınıflara göre bakıldığında ise; henüz eğitim almamış olan 1.Sınıflar ile (\%16.9) almış olan 3.Sınıflar (\%41.1) arasında beslenme dersinin davranış değişikliğine etkisi ile ilgili anlamlı farklılık saptand 1 ( $p=0.04)$. Beslenme dersinin alışkanlıkları üzerine etkili olduğunu belirten öğrenciler, en çok kahvaltı öğünü bakımından etkilendiklerini belirttiler (\%9.6).

Çalışmaya katılan 1.Sınıf öğrencilerinin \%44.2'sinin ve 3.Sınıf öğrencilerinin \%55.8'inin vücut ölçülerinden memnun olduğu saptandı fakat aralarında anlamlı fark bulunmadı $(\mathrm{p}=0.23)$.

Katılımcıların \%17.4'ünün beslenme programı uyguladığı belirlendi. Tüm öğrencilerin diyeti uygulama amacının sağlıklı yaşam olduğu (\%45.7), bilgilere diyetisyen aracılığıyla ulaşıldığ 1 bulunmuş olup $(\% 20), \% 44,3 \quad(n=51)$ 'ünün spor yaptığ 1 , spor aktivite dağılımlarına bakıldığında ise $\% 42$ 'sinin yürüyüş, \%13.9'unun fitness ve \%0.9'unun yüzdüğü tespit edildi.

Çalışmaya alınan tüm katılımcılar arasında \%70.4'ünün kronik hastalığının olmadığı ve \%93'ünün düzenli olarak herhangi bir ilaç kullanmadığı saptandı. Vitamin mineral takviyesi alan öğrencilerden $(\mathrm{n}=25) ; 12$ tanesinin $\mathrm{B}$ vitamini, 7 tanesinin multivitamin, ayrıca D vitamini, Fe ve $\mathrm{Ca}$ alan 2'şer öğrenci olduğu belirlendi.

\subsection{Tartışma}

Üniversite yıllarında öğrencilere beslenme yönünden yapılacak girişimler ve verilen eğitimler yanlış olan davranışlarının düzeltilmesinde ve ileride görülebilecek hastalıkların önlenmesinde yardımcı olabilir. Bu çalışmada da alınan beslenme eğitimin beslenme ve sağlık davranışları üzerine etkisi araştırıldı. Çalışmaya alınan 115 öğrencinin yaş ortalaması $21.2 \pm 2.38$ y1l olup, \%73.9'u (n=85) k1z ve \%26.1'i $(n=30)$ erkekti.

Birinci sınıf öğrencilerinin \%77.9'unun 3.Sınıf öğrencilerinin ise \%64.3'ünün "Normal” BKİ aralığında (18.5$24.9 \mathrm{~kg} / \mathrm{m} 2$ ) olduğu saptand1. Beden kütle indeksi $25 \mathrm{~kg} / \mathrm{m}^{2}$ 'den büyük olanların oranının 3.Sınıf öğrencilerinde 1.Sınıf öğrencilerine göre daha yüksek olduğu (\%26.8) ve katılımcı öğrencilerin \%2.6'sının (>30 kg/m2) "Şişman" olduğu belirlendi. Sağlık Bakanlığı Sağlık Araştırmaları Genel Müdürlüğünün araștırma sonucuna göre 19 yaș ve üzerindeki grubun BKİ ortalamasının Dünya Sağlık Örgütü obezite sınıflamasına göre "Hafif Şişman" seviyesinde bulunduğu, yetişkinlerde obezite prevelansının \%30.3 ve hafif şişmanlık sıklığının ise \%34.6 oranında olduğu ifade edilmiştir (Sağlık Bakanlığ 1,2014$)$.

Çalışmada 3.sınıflarda normal BKİ'ye sahip olma oranının, 1.Sınıflara göre daha düşük olmasının nedeni bu dönemde görmüş oldukları derslerin yükünün 1 .Sınıfa göre daha ağırlıklı olup, bunun sonucu olarak sedanter yaşama yönelmelerine bağlı olabilir.

Çalışmaya katılan öğrencilerin diğer antropometrik ölçümlerine bakıldığında bel çevresi $75 \mathrm{~cm}$ üzerinde olan öğrencilerin oranı 1.Sınıf öğrencilerinde \%67.8; 3.Sınıf öğrencilerinde ise \%39.3 oranındadır. 1. ve 3.Sınıf öğrencilerinin 
bel çevresi ölçümleri arasında anlamlı farklılık bulunmamaktadır $(\mathrm{p}=0.04)$. Bu farklılığın nedeni 3.Sınıfta adolesan dönemin sonlarına yakın olup vücut proporsiyonlarının stabilleşmesine bağlanabilir. Katılımcıların ortalama yă yüzdesi \%17-22 aralığında olup; 1.ve 3.Sınıflar arasında anlamlı fark saptanmamıştır. DSÖ’ nün sınıflamasına göre Bel/Kalça Oranı dağılımı kadınlarda $<0.85$ ve erkeklerde $<0.90$ olmalıdır (DSÖ, 2008).

Çalışmadaki tüm öğrencilerin (1.Sınıf ve 3.Sınıflar) \%76.5'inin akşam yemeğini atlamadığı ve \%66.1'inin evinde akşam yemeğini yediği bulunmuş olup, evde daha sağlıklı beslenebilmelerine bağlı olarak da çoğunun(\%71.3) "Normal" beden kütle indeksinde olduğu saptandı. Gençlerin aile ile birlikte yemek yemelerinin ve yemek yeme alışkanlıklarının Beden Kütle İndeksi (BKİ) ile ilişkisine dair yaptıkları başka bir çalışmada; 13-17 yaşları arası rastgele seçilen adölesanlara anket uygulanarak yeme alışkanlıkları sorgulanmış ve BKI'leri ölçülmüştür. Gençlerin yaklaşık \%60'ının aileleriyle haftada 5 veya daha çok öğünde bir araya geldiği belirlenmiştir. Sık olarak aile ile yemek yemenin meyve ve sebze tüketimini artırdığı ve kahvaltı etme alışkanlığını kazandırdığı bulunmuştur; ancak aile yemeklerine katılımla BKİ arası ilişki bulunmamıştır (Koseoglu \& Tayfur, 2017).

Yapılan çalışmada, bütün katılımcıların \%69.6'sının kahvaltı alışkanlığı olduğu, 1.Sınıfların \%67.8'inin ve 3.Sınıfların \%71.4'ünün sabahları kahvaltı yaptı̆̆ı saptandı. 1.Sınıflar ile 3.Sınıflar arasında kahvaltı alışkanlığ anlamlı fark saptanmadı $(\mathrm{p}=0,79)$. Katılımciların \%40.9'unun öğle yemeği yediği \%52.2'sinin öğle yemeği yemediği tespit edildi. Öğrencilerin beslenme alışkanlıklarını belirlemek için yapılan başka bir çalışmada günde üç ögün beslenenlerin oranı $\% 48.9$, üç öğünden az beslenenler $\% 24.8$ bulunmuş ve kahvaltı tüketim durumlarına göre \%34.4 öğrencinin kahvaltısını düzenli olarak yaptığı, sık kahvaltı etmeyenlerin ve hiç etmeyenlerin \%65.6 olduğu görülmüştür (Mazıcıoğlu \& Öztürk, 2003). Sakamaki ve arkadaşları ise yaptığı çalışmada; günde 3 öğün yemek yenilme oranının \%79.0 olduğunu tespit etmiştir (Sakamaki, Toyama \& Amamoto, 2005). Yardımcı'nın Ankara Üniversitesi Sağlık Bilimleri Fakültesi'nde yaptığı çalışmada en çok kahvaltı öğününün yapılmayıp, atlandığı bulunmuştur. Yapılan bu çalışmada ise, kahvaltı ögününü yapmayanların $\% 51.0$ oranında olduğu saptanmıştır. Kahvaltı ögününün düzenli olması, besin öğeleri yönünden ve öğrencilerin başarısına katkısı bakımından büyük değere sahiptir (Yardımcı \& Özçelik, 2015). Çünkü kahvaltının düzenli yapılması, enerji ve besin ögelerine katkı sağlamasının yanı sıra, okul başarısı üzerinde de olumlu etkiler yaratmaktadır (Ruxton \& Kirk, 1997).

Katılımcı öğrencilerin \%50.4'ünün kahvaltısını evde yaptığ ve 1 . Sınıf öğrencilerinin \%40'ının ve 3. Sınıf öğrencilerinin \%50'sinin kahvaltıda karışık besinleri tükettiklari belirlendi. Mazıcıoğlu'nun yürüttüğü çalışmada; üniversite öğrencilerinin sabah kahvaltısı ve akşam yemeğini evde yemeyi tercih ederken öğle yemekleri için okul yemekhanesini tercih ettiğini belirtmiştir(Mazıcıoğlu \& Öztürk, 2003).Yapılan çalışmada da benzer olarak bütün öğrencilerin \%60'ının kahvaltısını evde yaptığgi; \%67'sinin ise akşam yemeğini evde yediği saptanmıştır. Öğle yemeğini ise \%33.9'unun okulda yediği saptandı. Yılmaz ve arkadaşlarının yürüttüğü farklı çalışmada; öğrencilerin kahvaltı ögününde çay $(\% 81.1)$, simit ve ekmek (\%48.6) gibi gıdaları daha sık tükettikleri belirlenmiştir. (Yılmaz \& Özkan, 2007).

Birinci sınıfların beslenme eğitimi almadan \%33.9 olan öğle yemeği tüketimi eğitim sonrası \%48.2'ye yükseldiği görüldü $(\mathrm{p}=0.16)$. Katılımcıların tümünün öğle yemeğinde en fazla ettavuk-balık tükettiği (\%40.9), akşam yemeğinde de benzer olarak en fazla et-tavuk-balık tükettikleri (\%33), meyve yiyenlerinin oranının \%0.9 olduğu belirlendi. Yapılan başka bir çalışmada, öğle ve akşam yemeklerinde ekmek (\%62.9), çorba (\%83.4), pilav (\%58.3) ve makarna (\%55.4) gibi karbonhidrat ağırlıklı yiyecekleri daha sık, et (\%10.9), süt, yoğurt ve ayran (\%29.1) gibi protein ağırlıklı besinleri daha az tükettiklerini ve ara öğünlerde en fazla çay (\%65.7) içtikleri ifade edilmiştir (Y1lmaz \& Özkan, 2007).

Öğrencilerin \%53.9'unun öğle ve akşam yemeklerinde bazen hazır yemek tercih ettiği belirtildi. Hazır besin tercihinde bulunmayan öğrenci oranının \%19 olduğu saptandı. Çukurova Üniversitesinde 357 öğrencide yapılan bir çalışmada ise; fastfood türü gida tüketiminin $\% 87.7$ olduğu, bu ürünlerin hazırlanmasının ve tüketilmesinin fazla zaman gerektirmemesi, lezzetli ve fiyatının uygun olması nedenleriyle tercih edildiği belirtilmiştir (Özdinç, 2004). Fastfood beslenme üniversite öğrencileri arasında yaygındır. Üniversite öğrencilerinin fastfood besin tüketiminin olumsuz etkileri hakkında öğrencilerin bilgilendirilmesi, ev yemekleri tüketim alışkanlığının sıklaştırılması göz önünde bulundurulmalıdır (Subaşı, 2019).

Çalışma bulgularına göre, vitamin mineral takviyesi alan öğrencilerden $(\mathrm{n}=25) ; 12$ öğrencinin $\mathrm{B}$ vitamini, 7 öğrencinin multivitamin, ayrıca D vitamini, Fe ve Ca alan 2'şer öğrenci olduğu saptandı. Hemşirelik bölümü öğrencileri ile yapılan başka bir çalışmada en fazla kullanılan vitamin ve mineral takviyelerinin sırası ile demir preparatları $(\% 42.0)$, B grubu vitaminler (\%37.0), çoklu vitamin ve mineraller (\%13.6), kalsiyum (\%3.7) ve çoklu vitaminlerdir (\%3.7). 3. ve 4.Sınıf öğrencilerinin en sik B grubu vitaminleri, 1. ve 2.Sınıf öğrencilerinin ise en çok örneklem geneline aynı şekilde demir preparatları kullandıkları belirtilmiştir (Yılmaz \& Ayhan, 2017).

Katılımcıların, Hemşirelik Bölümü öğrencileri olduğu bu çalışmada, 1.Sınıfların \%24.1'inin; 3.Sınıfların ise \%33.3'ünün alkol kullandığ1; sigara tüketiminin ise 1.Sinıflarda $\% 18,9$; 3.Sınıflarda \%28.3 olduğu tespit edildi. Şimşek ve arkadaşlarının yürüttüğü çalışmaya göre; sigara kullanan öğrencilerin \%25.4, alkol ve madde kullananların ise $\% 2.5$ olduğu belirlenmiş olup, cinsiyete göre incelendiğinde, erkeklerin kılardan daha fazla alkol ve sigara tükettikleri belirtilmiştir (Şimşek, Koruk \& Altındağ, 2007). El Salvador'da yapılan diğer bir çalışmada (Springer ve ark.) üniversite öğrencilerinde sigara içme ve madde kullanım oranı sırasıyla; \%14.4 ve \%4.9 olarak saptanmıştır (Springer, Selwyn \& Kelder, 2006). Yapılan çalışmada, sigara içme oranının düşük olması sağlık konularında verilen eğitimden kaynaklanabilir.

Çalışmada, \%44.3 (n=51)'ünün spor yaptığı, spor aktivite dağılımlarına bakıldığında ise \%42'sinin yürüyüş, \%13.9'unun fitness ve \%0.9'unun yüzdüğü tespit edildi. Diğer bir çalışmanın sonuçlarına göre; üniversitelerin çeşitli fakülte ve bölümlerinde eğitim gören 1105 öğrencide, sigara kullanma ve fiziksel aktivite durumlarının sağlık alanında öğrenim gören öğrencilerin diğer bölümlere göre daha düşük olduğu belirlenmiştir (Ermiş, Doğan, Erilli \& Satıcı, 2015). Yapılan çalışmada \%44.3 kişinin yani az 
sayıda kişinin spor yapması yapılan fiziksel aktivitenin düşük olmasının nedeni ise sağlık bilimleri alanında alınan derslerin genellikle zaman bakımından yoğun ve uygulamaya dayalı olmasına bağlanabilir

\section{Sonuç}

Meslek sürecinde sağlıklı yaşam ile ilgili olarak çevrelerine katkı sağlayacak ve genel anlamda toplum sağlığını geliştirecek hemşirelik öğrencilerine verilen derslerin sağlıklı yaşam biçimi davranışları kazandırmaya yönelik olması büyük öneme sahiptir. Hemşirelik öğrencilerinin, sağlıklarını korumak, geliştirmek ve topluma uygun rol model olmalarını sağlamak için, verilecek beslenme eğitiminin arttırılması, üniversitelerde düzenli aralıklarla beslenme konularında konferanslar, seminerler ve söyleşiler düzenlenmesi, bu genç nüfusun sağlıklı yaşam biçimi davranışları ve sağlıklı diyet için teşvik edilmesi öneriler arasındadır. Bunlara ek olarak; bu davranışlar üzerinde etkili olan faktörlere yönelik olarak daha geniş kapsamlı ve çok merkezli araştırmaların planlanması yapılabilir.

\section{Kaynakça}

Baysal, A. (2007). Beslenme. Ankara: Şahin Matbaacılık.

Benjelloun, S. (2002). Nutrition transition in Morocco. Public Health Nutrition, 5(1a), 135-140.

Colić, Barić, I., Šatalić, Z., \& Lukešić, Ž. (2003). Nutritive value of meals, dietary habits and nutritive status in Croatian University students according to gender. International journal of food sciences and nutrition, 54(6), 473-484.

Demir, H., Özkorucuklu, Y.N. (2018). Üniversite Öğrencilerinde Süt ve Süt Ürünleri Tüketimi, Kalsiyumun Antropometrik Ölçümlerle İlişkisi. İstanbul Gelişim Üniversitesi Sağlık Bilimleri Dergisi, 5, 494-516.

Ermiş, E., Doğan, E., Erilli, N.A. \& Satıcı, A. (2015). Üniversite Öğrencilerinin Beslenme Alışkanlıklarının İncelenmesi: Ondokuz Mayıs Üniversitesi Örneği. Spor ve Performans Araştırmaları Dergisi, 6(1), 30-40.

Kaleli, S. (2017). Sakarya Üniversitesi Tıp Fakültesi öğrencilerinin beslenme alışkanlıkları. Online Türk Sağlık Bilimleri Dergisi, 2.2, 12-18.

Korkmaz, N. H. (2010). Uludağ Üniversitesi Öğrencilerinin Spor Yapma ve Beslenme Alışkanlıklarının İncelenmesi. Uludağ Üniversitesi Eğitim Fakültesi Dergisi, 23.2, 399-413.

Köseoğlu, S.Z.A., Tayfur, A.Ç. (2017). Adölesan Dönemi Beslenme ve Sorunları. Güncel Pediatri JCP, 15(2), 50-62.

Mazıcıŏlu, M., Öztürk, A. (2003). Üniversite 3 ve 4. Sınıf Öğrencilerinde Beslenme Alışkanlıkları ve Bunu Etkileyen Faktörler. Erciyes Tıp Dergisi, 25 (4), 172-178.

Özdinç, İ.Y. (2004). Üniversite Öğrencilerinin Fast-Food Tüketim Alışkanlıkları Ve Tüketim Noktası Tercihlerini Etkileyen Faktörler. Anatolia: Turizm Araştırmaları Dergisi. 15(1), 71-79.

Ruxton, C.H.S, Kirk, T.R. (1997). Breakfast: A Rewiev of Associations With Measures of Dietary Intake, Physiologyand Biochemistry. Br J Nutr, 78,199-213

Sakamaki, R., Toyama, K., Amamoto, R. et al. (2005). Nutritional Knowledge, Food Habits And Health Attitude of Chinese University Students A Cross Sectional Study. Nutrition Journal, 4(1), 4.

Sağlık Bakanlığg Araştırmaları Genel Müdürlüğü (2014). Türkiye Beslenme ve Sağlık Araştırması. Beslenme Durumu ve Alışkanlıklarının Değerlendirilmesi Sonuç Raporu. Sağlık Bakanlığı Yayın No: 931, Ankara.

Şimşek, Z., Koruk, İ., Altındağ, A. (2007). Harran Üniversitesi Tıp Fakültesi ve Fen-Edebiyat Fakültesi Birinci Sınıf

Öğrencilerinin Riskli Sağlık Davranışları. Toplum Hekimliği Bülteni, 3 (26).

Subaşı, Z. (2019). Özel Bir Kurumda Çalışan Bireylere Verilen Beslenme Eğitiminin Bireylerin Sağlıklı Beslenmeye İlişkin Alg1 ve Tutumlarına Etkisi. Türkiye, Başkent Üniversitesi Sağlık Bilimleri Enstitüsü Yüksek Lisans Tezi.

Springer, A.E., Selwyn, B.J. \& Kelder, S.H. (2006). A Descriptive Study Of Youth Risk Behavior In Urban and Rural Secondary School Students in El Salvador. BMC International Health and Human Rights, 6(1),3.

Utter, J., Denny, S., Robinson, E., Fleming, T., Ameratunga, S. \& Grant, S. Family Meals Among New Zealand Young People: Relationships with Eating Behaviors and Body Mass Index.J. Nutr. Educ. Behav., 45(1), 3-11.

World Health Organization. (2004). Appropriate Body-Mass Index For Asian Populations and Its Implications for Policy and Intervention Strategies. Lancet 363(9403), 157.

World Health Organisation. (2008). Waist Circumference and Waist-hip Ratio: Report of A WHO Expert Consultation. Geneva: World Health Organization, 8-11.

Yardımcı, H., Özçelik, A. (2015). Üniversite Öğrencilerinin Öğün Düzenleri ve Beslenme Eğitiminin Beslenme Bilgisine Etkisi, Beslenme Diyetetik Dergisi, 43(1), 19-26.

Yılmaz, E., Özkan, S., (2007) Üniversite Öğrencilerinin Beslenme Alışkanlıklarının İncelenmesi. Fırat Sağlık Hizmetleri Dergisi, 2(6),87-104.

Yılmaz, H.Ö., Ayhan, N.Y. (2017). Hemşirelik Öğrencilerinin Bazı Beslenme Alışkanlıklarının Değerlendirilmesi. Gümüşhane Üniversitesi Sağlık Bilimleri Dergisi, 6(1): 17 24.

Yfanti, E., Tsiriga, S., Yfantis, A., Tiniakou, I. \& Mastrapa, E. (2011). Nutrition Knowledge In Students of A Nursing School. Health Science Journal, 5(2), 485-489. 